\title{
Lactic Acid Bacteria Influence Silage Fermentation Characteristics and Bacterial Community Composition of Oat in Cold Region
}

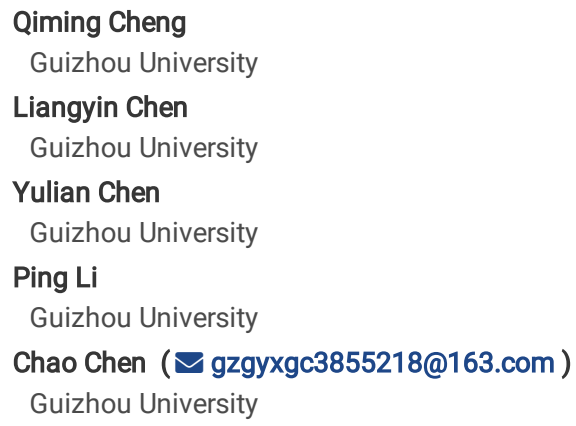




\section{Abstract}

Background: Lactic acid bacteria have been proposed for the control of undesirable fermentation and subsequently aerobic deterioration due to their ability to produce antimicrobial metabolites in silage mass. To investigate the effect of specific LAB on silage fermentation characteristics and bacterial community composition of oat in cold region, silages were treated without additives (CK) or with three LAB strains (LB, Lactobacillus buchneri, nLP, low temperature tolerant Lactobacillus planrtarum; pLP, phenyllactic acid-producing Lactobacillus plantarum), and then stored at ambient temperature ( $\left.<20{ }^{\circ} \mathrm{C}\right)$ for 30,60 and 90 days.

Results: Compared with $\mathrm{CK}$, inoculation of LAB decreased final $\mathrm{pH}$ value, butyric acid content, ammonia-N of total $\mathrm{N}$ and dry matter loss of silage. Treatments with $\mathrm{nLP}$ and pLP increased $(P<0.05)$ lactic acid content, whereas LB increased $(P<0.05)$ acetic acid content of silage. Lactobacillus and Leuconstoc dominated in the silages with relative abundance of $68.29 \sim 96.63 \%$. A prolonged storage period enhanced growth of Leuconstoc in pLP treated silage. In addition, pLP increased $(P<0.05)$ aerobic stability of silage as compared with $\mathrm{nLP}$.

Conclusions: In conclusion, inoculation of LAB improved silage fermentation and/or delayed aerobic deterioration by shifting bacterial community composition during ensiling. Phenyllactic acid-producing Lactobacillus plantarum as an inoculant exhibited potential for high quality silage production.

\section{Background}

Ensiling is an important technique for preserving fresh forage. However, the heavy distribution of undesirable microorganisms such as aerobic bacteria, yeasts and molds during ensiling and after exposure to air is a concerned issue in the world. Microbial additives have been applied to specifically elevate dominance of bacterial genera such as Lactobacillus, Pediococcus and Leuconstoc for optimizing silage fermentation process. Lactic acid bacteria (LAB) have been included in microbial additives, due to their active antagonistic metabolites including organic acids, fatty acids, ethonal hydrogen peroxide, acetoin, diacetyl, cyclic dipeptides, bacteriocins, or bacteriocin-like inhibitory substances during silage fermentation [1]. However, lower ambient temperature can undesirably delay or stop production of lactic and acetic acids during ensiling in cold region [2]. Recently, some specific LAB strains were used as inoculants for functional preservation of silage nutrients. For example, species of Lactobacillus buchneri (L. buchneri) and/or low temperature tolerant Lactobacillus plantarum (L. plantarum) is combined in microbial inoculants for functionally advancing silage fermentation process and reducing aerobic spoilage initiated by lactateassimilating yeasts in cold region [3].

Phenyllactic acid, as an eco-friendly antimicrobial agent with high stability under low temperature condition [4], can inhibit the growth of pathogenic bacteria, yeasts and molds in foods [5]. Phenyllactic acid is also investigated for animal feeding and disease prevention as an alternative to the use of antibiotic substances [6]. Some species of LAB such as L. plantarum, L. casei and P. acidlactici can produce phenyllactic acid [7]. Ström [8] firstly isolated a L. plantarum strain (MiLAB 393) from grass silage that produces broad-spectrum antifungal compounds, active against food-and feed-borne filamentous fungi and yeasts in a dual-culture agar plate assay. In our laboratory, a LAB strain L. plantarum was isolated from natural fermented-oat silage on the Qinghai Tibetan Plateau, and exhibited high phenyllactic acid-producing ability of $94.2 \mathrm{mg} / \mathrm{mL}$ in MRS broth incubated at $28{ }^{\circ} \mathrm{C}$ for 24 h. However, little information is how the strain affects quality of silage.

In addition, amounts of fresh oat were left on the land due to the unstable weather conditions on the Qinghai Tibetan Plateau. The ambient temperature falls to $<15{ }^{\circ} \mathrm{C}$, which usually results in unfinished fermentation during ensiling and rapid deterioration after exposure to air. Hence, the objective of the present study was to compare the effects of specific LAB including $L$. buchneri, low temperature tolerant $L$. plantarum and phenyllactic acid-producing $L$. plantarum on the fermentation characteristics, bacterial community composition and aerobic stability of oat silage stored on the Qinghai Tibetan Plateau. Our hypothesis was that the three LAB strains could functionally improve silage quality of oat under low storage temperature $\left(<20^{\circ} \mathrm{C}\right)$ condition.

\section{Results And Discussion}

The chemical compositions and number of LAB and yeasts of fresh forage were shown in Table 1. The additive, storage period and their interaction significantly $(P<0.05)$ affected the DM loss and WSC of silages. The contents WSC of silages tended to decrease and DM loss tended to increase with storage period $(P<0.05)$. The DM content of fresh forage was $24.55 \%$. The WSC content $(8.91 \% \mathrm{DM})$ of fresh forage was sufficient for an adequate fermentation process during ensiling. Inoculations of functional LAB treatments decreased DM loss as compared with the control silage in our study, that because LAB causing reduction of DM loss in silage fermentation [9]. The significant higher DM loss reported in LB silage than nLP and pLP silages was due to the production of carbon dioxide by LB (L. buchneri) through heterofermentative fermentation, resulting in considerable DM losses [9]. However, the epiphytic LAB count ( $2.81 \mathrm{lg} \mathrm{cfu} / \mathrm{g}$ of FM) on the plants was below the minimum requirement ( $5.0 \mathrm{lg} \mathrm{cfu} / \mathrm{g} \mathrm{FM})$ for high quality silage. In addition, high yeasts count (4.71 lg cfu/g of FM) distributed on the plants may increase potential for more DM loss during ensiling. As speculated, the control silage showed poor fermentation with $\mathrm{pH}$ of $4.45 \sim 4.55$, butyric acid of $0.13 \sim 0.16 \% \mathrm{DM}$ and ammonia-N of 14.3 18.72 \% TN (Table 2). The counts of LAB and yeasts of fresh forage in our study were lower than the results of Wang [10] who reported that the LAB and yeasts counts of fresh oat were 5.61 and $8.45 \mathrm{lg}$ cfu/g of FM, respectively. A similar situation was also observed by Chen [3], who reported that both forages growing at different geographic locations but with similar maturity stage had inconsistent microbial composition and structure on the plants, which were caused by ambient temperature differences [11].

The additive, storage period and their interaction significantly $(P<0.05)$ affected the lactic acid, ammonia- $\mathrm{N}$ and aerobic stability of silages (Table 2$)$. In the present study, inoculations of functional LAB increased lactic acid content and decreased pH value, butyric acid content and ammonia- $\mathrm{N}$ of total $\mathrm{N}$ of silages. The fermentation quality of nLP silage was the best, mainly reflected in that nLP silage had the lowest pH (< 4.2) and ammonia-N (10.25 12.13\%TN), and the highest LA content (> $3 \% \mathrm{DM})$. This indicated that nLP strain could better play its role in low temperature environment than other LAB strains [3]. Inoculation of LB increased acetic acid content of silage. Similar result on oat silage was from Gomes [12]. Moreover, the concentration of lactic acid occurred highest and 
changed little in nLP-inoculated silage. This was probably because of the metabolism of exogenous strains of $L$. plantarum, functionally capable of quickly production of lactic acid under low temperature condition [3].

In the present study, LB $(L$. buchneri) silage had the highest $(P<0.05)$ aerobic stability $(>170 \mathrm{~h})$ than other silages. The use of $L$. buchneri to improve aerobic stability has proved valuable, due to its production of acetic acid [13]. A similar situation was found by Kleinschmit and Kung [14] who evaluated 43 studies that inoculated $L$. buchneri in different forages to ensilage and reported that inoculant improved the aerobic stability of silages. In fact, the aerobic stability of pLP inoculated silages also exhibited higher stability than control and $\mathrm{nLP}$ inoculated silages (Table 2). This may be due to the fact that production of phenyllactic acid (14.4 16.8\%oDM) and acetic acid (0.36 0.38\%DM) during ensiling could damage the membrane integrity, interrupted the outer membrane permeability, and then interact with microbial genomic DNA in the manner of intercalation $[5,15]$.

Phenyllactic acid has recently been proposed for their activities against bacteria, yeasts and molds in foods [5] and animal diet [6] for their very low toxicity for animal and humans. In addition, phenyllactic acid could be produced at a low-cost by effectively fermentation modes through lactic acid bacteria [16]. In our study, a high phenyllactic acid content (14.4 16.8\%oDM) was detected in pLP silage, but not in the other silages. This indicated that the phenyllactic acid produced by pLP strain could be effectively used as an antifungal compound to delay the growth of a variety of fungal contaminants and also to extend the self life of feed stuffs [17]. At the same time, Phenyllactic acid-producing LAB exhibited potential for enhancing quality of fermented-products. Compared with LB and control, the inoculation of pLP did shift fermentation characteristics with high lactic acid (2.43 2.86\%DM) and low butyric acid (0.05 0.06\%DM) of silage. However, the pLP inoculated silage showed higher $(P<0.05)$ ammonia-N of total $N$ and numbers of yeasts and lower LAB of than $n L P$ inoculated silage. This may be due to the fact that low temperature tolerant $L$. plantarum could robust for rapid pH reduction to inhibit plant inherent proteolysis and undesirable microorganisms such as Clostridia [3].

It is well known that natural fermentation of forages depends on epiphytic microflora especially count of LAB in an anaerobic environment [18]. In addition, various bacterial communities and successions have been found in different pre- and post-silage forages [19]. Therefore, bacterial community composition plays a vital role in silage fermentation, and knowing community composition is a necessary condition to understand the complex process of ensiling [20]. Next generation sequencing could help us better understanding on the silage fermentation pattern. In the present study, the bacterial alpha diversity indices of OTU and Chao 1 increased as the storage period prolonged (Fig.1). This may be due to the higher silage pH of $>4.2$, which exert a limited effect on most undesirable acid tolerant microbes in silage [10]. The main microorganisms of fresh oat were uncultured bacterium (37.13\%), Pantoea (33.12\%) and Pseudomonas (19.55\%), which differs from previous results showing that Enterobacter, Pantoea and Serraia were the predominant genera in fresh soybeans [21], and Agrobacterium, Microbacterium and Sphingobacterium were dominated the microbial composition in fresh whole crop corn [20]. Previous studies have illustrated that colonization of plant surfaces by bacteria depends on many factors, including material species, climate, period of duration, geographical location, solar radiation intensity and the type of fertilizer used [10, 12, 22].

Over the 30-90 $\mathrm{d}$ of ensiling, the bacterial communities in the silages were highly dominated by the genera belonging to LAB while undesirable microbial communities were extensively inhibited (Fig.2). Genera of Lactobacillus and Leuconostoc dominated in the silages, with relative abundance of 68.29 96.63\%. Similar observation was reported by Xu [20], who found that most of the undesirable microorganisms were inhibited after fermentation, and Lactobacillus (> $98 \%$ ) was the dominant genera in corn silages stored for 90 days. Lactobacillus is a rod-shaped LAB that can convert plant carbohydrates into LA to decline $\mathrm{pH}$ value of silage. In our study, $\mathrm{nLP}$ silages had higher relative abundance of Lactobacillus than other silages. This is the main reason why $\mathrm{nLP}$ silages had the highest LA content and the lowest $\mathrm{pH}$ than other group silages (Table 2). Compared with control, inoculations of functional LAB increased the relative abundance of Lactobacillus by $21.62 \sim 75.88 \%$, but decreased that of Leuconotoc by $16.88 \sim 75.05 \%$ in silages. The pLP inoculated silage showed low relative abundance of Lactobacillus and high relative abundance of Leuconostoc in relative to LB and $\mathrm{nLP}$ inoculated silages. A prolonged storage period reduced the positive effects from $L A B$ inoculation on increase in relative abundance of Lactobacillus and decrease in relative abundance of Leuconstoc in silage, which increased potential for aerobic deterioration [23].

\section{Conclusions}

Inoculation of specific LAB could improve fermentation quality and shift bacterial community composition of oat silage. Both L. buchneri and pheneyllactic acid-produced L. plantarum increased aerobic stability of silage. In particular, phenyllactic acid-produced L. plantrarum, as a silage inoculant, enriched Leuconstoc and Lactobacillus during ensiling.

\section{Methods}

\section{Materials and silage preparation}

Experiment was conducted at the Hongyuan experimental base of Sichuan Academy of Grassland Sciences ( $44^{\circ} 53^{\prime} \mathrm{N}, 7^{\circ} 41^{\prime} \mathrm{E}$, altitude $\left.3500 \mathrm{~m}\right)$, which locates on the Qinghai Tibetan Plateau in P. R. China. Oat at milk stage was harvested as ensiling material at September 10, 2020. The harvested oat was chopped using a chopper, and randomly divided into thirty-six 10-kg piles to obtain nine replications per treatment. The treatments were as follows: control without additives (CK); LB, L. buchneri isolated from natural-fermented silage; nLP, low temperature tolerant L. plantarum isolated from natural fermented-reed canary grass silage [3]; pLP, phenyllactic acid-producing L. plantarum isolated from natural fermented-oat silage and preserved at China General Microbiological Cultural Collection Center (No.14117). To reduce negative effects from addition amounts, each LAB was applied at a rate of $10^{6} \mathrm{cfu} / \mathrm{g}$ of fresh matter (FM).

Each LAB was separately diluted in sterilized water, and sprayed uniformly onto the forage using a hand sprayer, which was constantly hand mixed and yield applying amount of $4 \mathrm{~L}$ inoculant-diluted solution/t of fresh forages. The same amount of water was added to the CK treatment. And, the treated forage from each pile was packed in a $20 \mathrm{~L}$ plastic silo equipped with a lid that only enabled gas release. The density of all silages was about $500 \pm 25 \mathrm{~kg} / \mathrm{m}^{3}$ on $\mathrm{FM}$ 
basis. Three of silage silos with same treatment were sampled after 30,60 and 90 days of ensiling at ambient temperature of $<20{ }^{\circ} \mathrm{C}$. Samples from the fresh forage and the silages were subject to analysis of chemical composition, aerobic stability, microbial population and/or bacterial community.

\section{Chemical analysis}

Samples were dried at $65{ }^{\circ} \mathrm{C}$ for a constant weight to determine dry matter (DM) content, and then ground through $0.20 \mathrm{~mm}$ sieve for water soluble carbohydrate (WSC) analysis by the method of McDonald [24]. The DM loss was calculated by formula as follows: DM loss (\%) = $100 \times$ [1 - (pre-ensiled forage weight / silage weight at opening)].

Fresh sample of $20 \mathrm{~g}$ was mixed with $180 \mathrm{~mL}$ ultrapure water for $3 \mathrm{~min}$ in a stomacher blender. The $\mathrm{pH}$ of filtrate was determined by $\mathrm{pH}$ meter. Filtrate of about $10 \mathrm{~mL}$ was subjected to centrifugation $\left(4500 \times \mathrm{g}, 15 \mathrm{~min}, 4^{\circ} \mathrm{C}\right)$, and the supernatant was analyzed for lactic acid, acetic acid, propionic acid and butyric acid using high performance liquid chromatography [25]. Identification and quantification of phenyllactic acid was determined by the method of Jung [5]. Ammonia nitrogen was determined by methods of Broderick \& Kang [26].

\section{Microbial population analysis}

Microbial population on fresh samples was determined by the method of Cai [27]. Ten grams of each fresh sample were put into a sterile glass bottle, suspended in $90 \mathrm{~mL}$ of sterile water, and homogenized for $2 \mathrm{~h}$ in a laboratory blender (LB20ES, Shanghai Prime Science Co., Ltd, Shanghai, China). Serial dilutions were made. The number of LAB were counted on MRS agar (GCM188, Land Bridge Technology Co., Ltd, Beijing, China), incubated at $37^{\circ} \mathrm{C}$ for $48 \mathrm{~h}$. Yeasts were counted on malt extract agar with $1.5 \mathrm{mg} / \mathrm{L}$ Tetracycline (CM173, Land Bridge Technology Co., Ltd, Beijing, China), incubated at $30{ }^{\circ} \mathrm{C}$ for $48 \mathrm{~h}$. Yeasts were distinguished from molds by colony appearance and observation of cell morphology.

\section{Bacterial community analysis}

The extraction of bacterial DNA from fresh sample was determined by the method of Li [25]. In brief, Phusion®High-Fidelity PCR Master Mix (New England Biolabs) was used to carry out PCR reactions, following the manufacturer's instructions. The primer $515 \mathrm{~F}$ and $907 \mathrm{R}$ was chosen to amplify the V4-V5 region of 16S rRNA gene. The PCR amplicons were then sequenced by using an Illumina MiSeq PE2500 platform at Novogene Company (Beijing, China). After sequencing, paired reads were merged using FLASH (V 1.2.7), and filtered by QIIME. The uparse method was employed to assign operational taxonomic units (OTUs) to the $16 \mathrm{~S}$ rRNA at a cutoff level of $3 \%$ on the Usearch software platform (version 7.1). Based on OTUs results, the alpha indices were calculated with QIIME (Version 1.7.0) and displayed with R software (Version 2.15.3).

\section{Aerobic stability}

The aerobic stability of silage was measured by the method of Kung [13]. At silo opening, approximately $5.0 \mathrm{~kg}$ of silage from each silo was returned to clean buckets without packing under air-controlled temperature of $25 \pm 0.5^{\circ} \mathrm{C}$. A thermocouple probe was placed in the geometric center of each silage mass, and temperatures were recorded by a data logger (YA204R, YADU Electronic Technology Co., Ltd, Shanghai, China) every 30 minutes. Silos were covered with 2 layers of cheesecloth and exposed to air. Aerobic stability was determined as the number of hours before the temperature of the silage mass increased $2{ }^{\circ} \mathrm{C}$ above ambient temperature of each silage mass.

\section{Statistical analysis}

Data was analyzed as a $4 \times 3$ factorial arrangement in a completely randomized design. The model included the fixed effects of additive (A), storage period $(S)$, and their interaction $(A \times S)$. Data were analyzed using the Fit Model procedure of JMP (SAS Institute Inc., Cary, NC), and differences are reported as significant when $P \leq 0.05$. Means were separated by Tukey's test $(P \leq 0.05)$.

\section{Abbreviations}

A: additive; AxS: Interaction between additive and storage period; CK: Control without additives; DM: Dry matter; FM: Fresh matter; nd: No detected; LAB: Lactic acid bacteria; LB: Lactobacillus buchneri; NIp: Low temperature tolerant Lactobacillus planrtarum; pLP: phenyllactic acid-producing Lactobacillus plantarum; S: Storage period; SEM: Standard error of mean; WSC: Water soluble carbohydrate;

\section{Declarations}

\section{Acknowledgments}

Not applicable.

\section{Funding}

This work was supported by Sichuan Operating expenses for basic scientific research (2020), Guizhou Talent Base of Grassland Ecological Animal Husbandry (RCJD2018-13) and Guizhou University Laboratory Open Project (SYSKF2021-017).

\section{Availability of data and materials}

Not applicable. 


\section{Authors' contributions}

PL and CC designed the experiments and revised the manuscript. QMC, CLY and YLC performed the experiments. QMC and CLY wrote the manuscript. PL and QMC carried out the data analysis. All authors reviewed and considered the manuscript.

\section{Ethics approval and consent to participate}

Not applicable.

\section{Consent for publication}

Not applicable.

\section{Competing interests}

The authors declare that they have no competing interests.

\section{Publisher's Note}

Springer Nature remains neutral regarding jurisdictional claims in published maps and institutional affiliations.

\section{Author details}

${ }^{1}$ College of Animal Science, Guizhou University, Guiyang 550025, China. ${ }^{2}$ Sichuan Academy of Grassland Sciences, Chengdu 611731, China.

\section{References}

1. Crowley S, Mahony J, van Sinderen D. Current perspectives on antifungal lactic acid bacteria as natural bio-preservatives. Trends Food Sci Tech. 2013;33:93-109.

2. Bernardes TF, Daniel JLP, Adesogan AT, McAllister TA, Drouin P, Nussio LG, Huhtanen P, Tremblay GF, Bélanger G, Cai Y. Silage review: Unique challenges of silages made in hot and cold regions. J Dairy Sci. 2018;101:4001-4019.

3. Chen L, Li P, Gou W, You M, Cheng Q, Bai S, Cai Y. Effects of inoculants on the fermentation characteristics and in vitro digestibility of reed canary grass (Phalaris arundinacea L.) silage on the Qinghai-Tibetan Plateau. Anim Sci J. 2020;91:e13364.

4. Cortés-Zavaleta O, López-Malo A, Hernández-Mendoza A, García HS. Antifungal activity of lactobacilli and its relationship with 3-phenyllactic acid production. Int J Food Microbiol. 2014;173:30-35.

5. Jung S, Hwang H, Lee J. Effect of lactic acid bacteria on phenyllactic acid production in kimchi. Food Control. 2019;106:106701.

6. Kim DW, Kim JH, Kang HK, Akter N, Kim MJ, Na JC. Dietary supplementation of phenyllactic acid on growth performance, immune response, cecal microbial population, and meat quality attributes of broiler chickens. J Appl Poultry Res. 2014;23:661-670.

7. Bustos AY, Font De Valdez G, Gerez CL. Optimization of phenyllactic acid production by Pediococcus acidilactici CRL 1753. Application of the formulated bio-preserver culture in bread. Biol Control. 2018;123:137-143.

8. Ström K, Sjögren J, Broberg A, Schnürer J. Lactobacillus plantarum MiLAB 393 produces the antifungal cyclic dipeptides cyclo (I-Phe-I-Pro) and cyclo (IPhe-trans-4-OH-I-Pro) and 3-phenyllactic acid. Appl Environ Microb. 2002;68: 4322-4327.

9. McDonald P, Henderson N, Heron S. The Biochemistry of Silage. Chalcombe Publications, Marlow. 1991.

10. Li P, Zhang Y, Gou W, Cheng Q, Bai S, Cai Y. Silage fermentation and bacterial community of bur clover, annual ryegrass and their mixtures prepared with microbial inoculant and chemical additive. Anim Feed Sci Tech. 2019;247:285-293.

11. Broderick GA, Kang JH. Automated simultaneous determination of Ammonia and total amino acids in ruminal fluid and in vitro media. $\mathrm{J}$ Dairy Sci. 1980;63:64-75.

12. Cai Y, Benno Y, Ogawa M, Kumai S. Effect of applying lactic acid bacteria isolated from forage crops on fermentation characteristics and aerobic deterioration of silage. J Dairy Sci. 1999;82:520-526.

13. Kung L, Smith ML, Benjamim Da Silva E, Windle MC, Da Silva TC, Polukis SA. An evaluation of the effectiveness of a chemical additive based on sodium benzoate, potassium sorbate, and sodium nitrite on the fermentation and aerobic stability of corn silage. J Dairy Sci. 2018;101:5949-5960.

14. Cai Y, Fujita Y, Murai M, Ogawa M, Yoshida N, Kitamura A, Miura T. Application of lactic acid bacteria (Lactobacillus plantarum Chikuso-1) for silage preparation of forage paddy rice. J Jap Soc GrassI Sci. 2003;49:477-485.

15. Wang S, Zhao J, Dong Z, Li J, Kaka NA, Shao T. Sequencing and microbiota transplantation to determine the role of microbiota on the fermentation type of oat silage. Bioresource Technol. 2020;309:123371.

16. Singh VK, Shukla KS, Singh AK. Impact of Climate Change on Plant-Microbe Interactions under Agroecosystems. Pages $153-179$ In: Climate Change and Agricultural Ecosystems, Choudhary, K.K., Kumar, A., Singh, A.K. (eds), Woodhead Publishing. 2019.

17. Gomes ALM, Jacovaci FA, Bolson DC, Nussio LG, Jobim CC, Daniel JLP. Effects of light wilting and heterolactic inoculant on the formation of volatile organic compounds, fermentative losses and aerobic stability of oat silage. Anim Feed Sci Tech. 2019;247:194-198.

18. Kleinschmit, DH, Kung L. A meta-analysis of the effects of Lactobacillus buchneri on the fermentation and aerobic stability of corn and grass and smallgrain silages. J dairy Sci. 2006;89(10):4005-4013. 
19. Ning Y, Yan A, Yang K, Wang Z, Li X, Jia Y. Antibacterial activity of phenyllactic acid against Listeria monocytogenes and Escherichia coli by dual mechanisms. Food Chem. 2017;228:533-540.

20. Kawaguchi H, Teramura H, Uematsu K, Hara KY, Hasunuma T, Hirano K, Sazuka T, Kitano H, Tsuge Y, Kahar P, Niimi-Nakamura S, Qinuma K, Takaya N, Kasuga S, Qgino C, Kondo A. Phenyllactic acid production by simultaneous saccharification and fermentation of pretreated sorghum bagasse. Bioresource Technol. 2015;182:169-178.

21. Prema P, Smila D, Palavesam A, Immanuel G. Production and characterization of an antifungal compound (3-phenyllactic acid) produced by Lactobacillus plantarum strain. Food Bioprocess Tech. 2010;3(3):379-386.

22. Jones DJC. The biochemistry of silage. J Agr Sci. 1991;117:386.

23. Parvin S, Wang C, Li Y, Nishino N. Effects of inoculation with lactic acid bacteria on the bacterial communities of Italian ryegrass, whole crop maize, guinea grass and rhodes grass silages. Anim Feed Sci Tech. 2010;160(3-4):160-166.

24. Xu D, Ding W, Ke W, Li F, Zhang P, Guo X. Modulation of metabolome and bacterial community in whole crop corn silage by inoculating homofermentative Lactobacillus plantarum and heterofermentative Lactobacillus buchneri. Front Microbiol. 2019;9:3299.

25. Ni K, Wang F, Zhu B, Yang J, Zhou G, Pan Y, Tao Y, Zhong J. Effects of lactic acid bacteria and molasses additives on the microbial community and fermentation quality of soybean silage. Bioresource Technol. 2107;238:706-715.

26. Pang H, Qin G, Tan Z, Li Z, Wang Y, Cai Y. Natural populations of lactic acid bacteria associated with silage fermentation as determined by phenotype, 16S ribosomal RNA and recA gene analysis. Syst Appl Microbiol. 2011;34(3):235-241.

27. Liu B, Huan H, Gu H, Xu N, Shen Q, Ding C. Dynamics of a microbial community during ensiling and upon aerobic exposure in lactic acid bacteria inoculation-treated and untreated barley silages. Bioresource Technolo. 2019;273:212-219.

\section{Tables}

Table 1 The chemical and microbial compositions of fresh forage

\begin{tabular}{|c|c|c|c|c|c|c|c|c|c|c|c|c|c|c|c|}
\hline \multirow[t]{2}{*}{ Item } & \multirow{2}{*}{$\begin{array}{l}\text { Fresh } \\
\text { forage }\end{array}$} & \multicolumn{3}{|l|}{ CK } & \multicolumn{3}{|l|}{ LB } & \multicolumn{3}{|l|}{$\mathrm{nLP}$} & \multicolumn{3}{|l|}{$\mathrm{pLP}$} & \multirow[t]{2}{*}{ SEM } & \multirow{2}{*}{$\frac{P-1}{A}$} \\
\hline & & $30 \mathrm{~d}$ & $60 \mathrm{~d}$ & $90 \mathrm{~d}$ & $30 \mathrm{~d}$ & $60 \mathrm{~d}$ & $90 \mathrm{~d}$ & $30 \mathrm{~d}$ & $60 \mathrm{~d}$ & $90 \mathrm{~d}$ & $30 \mathrm{~d}$ & $60 \mathrm{~d}$ & $90 \mathrm{~d}$ & & \\
\hline $\mathrm{DM}, \%$ & 24.55 & 25.46 & 26.59 & 25.72 & 26.12 & 27.75 & 25.27 & 25.29 & 26.18 & 26.44 & 26.38 & 26.00 & 26.82 & 0.72 & 0.1 \\
\hline $\begin{array}{l}\text { DM } \\
\text { loss, \% }\end{array}$ & - & $3.17 c$ & $3.48 b$ & $3.86 a$ & $2.65 d$ & $2.82 d$ & $3.41 b c$ & $1.81 \mathrm{~g}$ & $1.96 \mathrm{fg}$ & $2.08 f$ & $2.21 \mathrm{e}$ & 2.34de & $2.58 \mathrm{~d}$ & 0.26 & $<0$ \\
\hline $\begin{array}{l}\text { WSC, } \\
\% \mathrm{DM}\end{array}$ & 8.91 & $2.18 b$ & $1.98 \mathrm{bc}$ & $0.17 d$ & $2.15 b$ & $1.87 \mathrm{c}$ & $0.20 \mathrm{~d}$ & $3.19 a$ & $2.28 \mathrm{~b}$ & $2.16 \mathrm{~b}$ & $3.21 \mathrm{a}$ & $2.19 b$ & $0.32 d$ & 1.02 & $<0$ \\
\hline $\begin{array}{l}\text { LAB, Ig } \\
\mathrm{cfu} / \mathrm{g} \\
\text { of FM }\end{array}$ & 2.81 & $5.55 d$ & $5.43 d$ & $5.58 d$ & $8.12 b$ & $9.42 a$ & $9.66 a$ & $9.45 a$ & $9.88 a$ & $9.52 \mathrm{a}$ & $6.89 c$ & $7.45 c$ & $7.16 \mathrm{c}$ & 0.54 & $<0$ \\
\hline $\begin{array}{l}\text { Yeasts, } \\
\text { lg } \\
\mathrm{cfu} / \mathrm{g} \\
\text { of FM }\end{array}$ & 4.17 & 3.1 & 3.36 & 3.48 & $<1.0$ & $<1.0$ & $<1.0$ & $<1.0$ & $<1.0$ & $<1.0$ & 2.22 & 2.14 & 2.10 & - & - \\
\hline
\end{tabular}

A, additive; A×S, interaction between additive and storage period; CK, control without additives; DM, dry matter; LAB, lactic acid bacteria; LB, Lactobacillus buchneri, nLP, low temperature tolerant Lactobacillus plantarum; pLP, phenyllactic acid-producing Lactobacillus plantarum; S, storage period; SEM, standard error of mean; WSC, water soluble carbohydrates. Means in rows with unlike superscripts differed at level of $P<0.05$.

Table 2 The fermentation quality and aerobic stability of silages after30, 60 and 90 days of ensiling 


\begin{tabular}{|c|c|c|c|c|c|c|c|c|c|c|c|c|c|}
\hline \multirow[t]{2}{*}{ Item } & \multicolumn{3}{|l|}{ CK } & \multicolumn{3}{|l|}{ LB } & \multicolumn{3}{|l|}{$\mathrm{nLP}$} & \multicolumn{3}{|l|}{$\mathrm{pLP}$} & \multirow[t]{2}{*}{ SEM } \\
\hline & $30 \mathrm{~d}$ & $60 d$ & $90 \mathrm{~d}$ & $30 \mathrm{~d}$ & $60 \mathrm{~d}$ & $90 \mathrm{~d}$ & $30 \mathrm{~d}$ & $60 d$ & $90 \mathrm{~d}$ & $30 \mathrm{~d}$ & $60 d$ & $90 \mathrm{~d}$ & \\
\hline $\mathrm{pH}$ & $4.55 a$ & $4.45 b$ & 4.51ab & $4.41 b c$ & $4.34 \mathrm{c}$ & $4.38 \mathrm{bc}$ & $4.18 d$ & $4.19 d$ & $4.14 d$ & $4.42 b c$ & $4.41 \mathrm{bc}$ & $4.44 b$ & 0.06 \\
\hline $\begin{array}{l}\text { Phenyllactic } \\
\text { acid, \%oDM }\end{array}$ & $<0.1$ & nd & nd & nd & nd & nd & nd & nd & nd & 16.8 & 14.4 & 15.1 & - \\
\hline $\begin{array}{l}\text { Lactic acid, } \\
\text { \% DM }\end{array}$ & $2.02 \mathrm{e}$ & $1.88 \mathrm{e}$ & $1.89 \mathrm{e}$ & $2.26 \mathrm{~cd}$ & $2.22 \mathrm{~cd}$ & $2.23 \mathrm{~cd}$ & $3.02 a$ & $3.19 a$ & $3.06 a$ & $2.86 b$ & $2.49 c$ & $2.43 \mathrm{~cd}$ & 0.39 \\
\hline $\begin{array}{l}\text { Acetic acid, } \\
\% \text { DM }\end{array}$ & 0.24 & 0.28 & 0.32 & 0.71 & 0.79 & 0.80 & 0.17 & 0.18 & 0.16 & 0.36 & 0.38 & 0.37 & 0.14 \\
\hline $\begin{array}{l}\text { Propionic } \\
\text { acid, \% DM }\end{array}$ & nd & nd & 0.14 & 0.25 & 0.20 & 0.22 & nd & nd & 0.05 & nd & 0.15 & 0.17 & 0.01 \\
\hline $\begin{array}{l}\text { Butyric acid, } \\
\text { \% DM }\end{array}$ & 0.16 & 0.14 & 0.13 & 0.10 & 0.08 & 0.09 & 0.08 & 0.09 & 0.09 & 0.06 & 0.06 & 0.05 & 0.01 \\
\hline $\begin{array}{l}\text { Ammonia- } \\
\mathrm{N}, \% \mathrm{TN}\end{array}$ & $14.3 \mathrm{c}$ & $18.72 a$ & $18.5 a$ & $12.61 d$ & $14.27 \mathrm{c}$ & $15.07 \mathrm{~b}$ & $10.25 \mathrm{e}$ & $11.48 \mathrm{e}$ & $12.13 \mathrm{e}$ & $12.31 d$ & $13.42 \mathrm{c}$ & $14.97 \mathrm{~b}$ & 1.04 \\
\hline $\begin{array}{l}\text { Aerobic } \\
\text { stability, h }\end{array}$ & $86 e$ & $84 \mathrm{e}$ & $98 d$ & $171 a$ & $179 a$ & $184 a$ & $96 d$ & $100 d$ & $98 d$ & $118 c$ & $122 \mathrm{c}$ & $142 b$ & 8.41 \\
\hline
\end{tabular}

A, additive; A×S, interaction between additive and storage period; CK, control without additives; DM, dry matter; LB, Lactobacillus buchneri, nd, no detected; $\mathrm{nLP}$, low temperature tolerant Lactobacillus plantarum; pLP, phenyllactic acid-producing Lactobacillus plantarum; S, storage period; SEM, standard error of mean; $\mathrm{TN}$, total nitrogen. Means in rows with unlike superscripts differed at level of $P<0.05$.

\section{Figures}
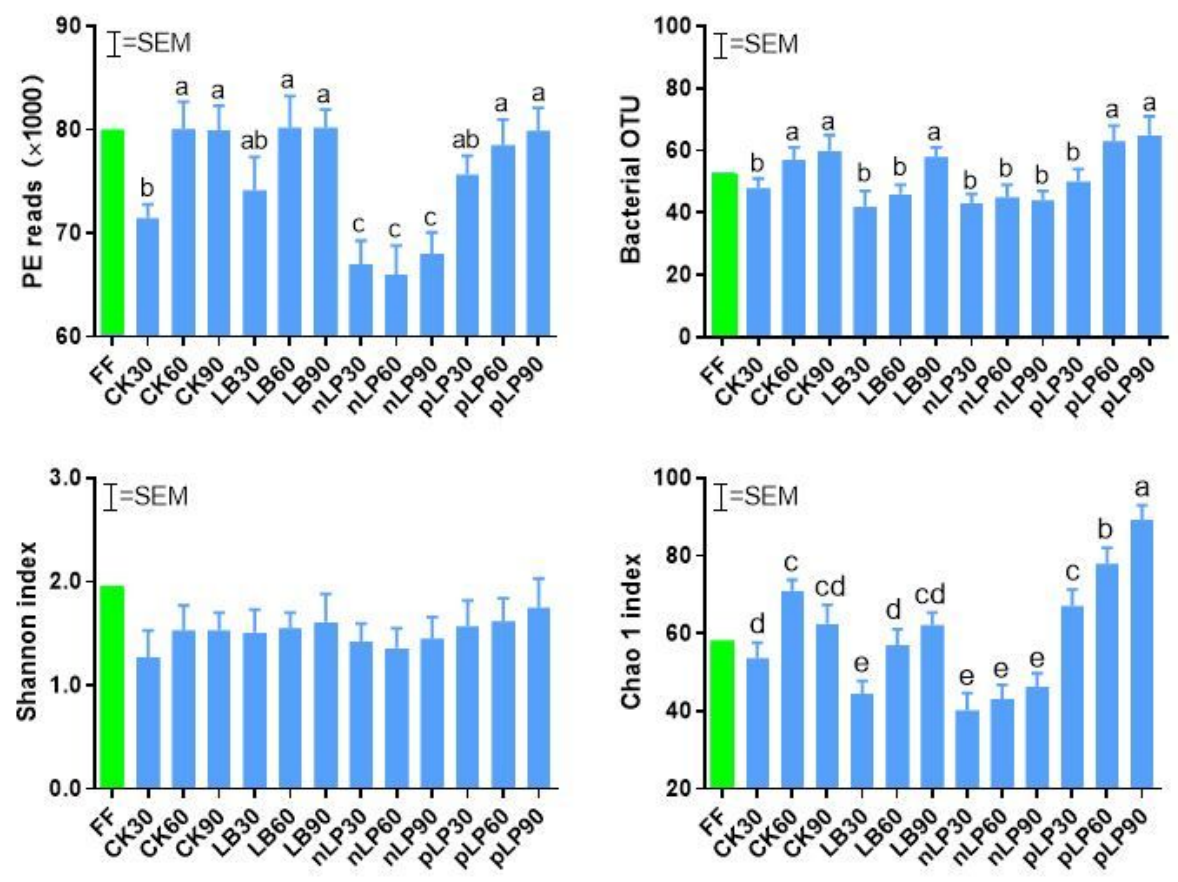

\section{Figure 1}

The bacterial community index of fresh forage (FF) and control without additives (CK) or with functional LAB (LB, L. buchneri; $n L P$, low temperature tolerant L. plantarum; pLP, phenyllactic acid-producing L. plantarum; each application rate of $106 \mathrm{cfu} / \mathrm{g} \mathrm{FM}$ ), and ensiled for $30 \mathrm{~d}, 60 \mathrm{~d}$ and $90 \mathrm{~d}$. Bars with different letters (a-e) differ $(\mathrm{P}<0.05)$. 


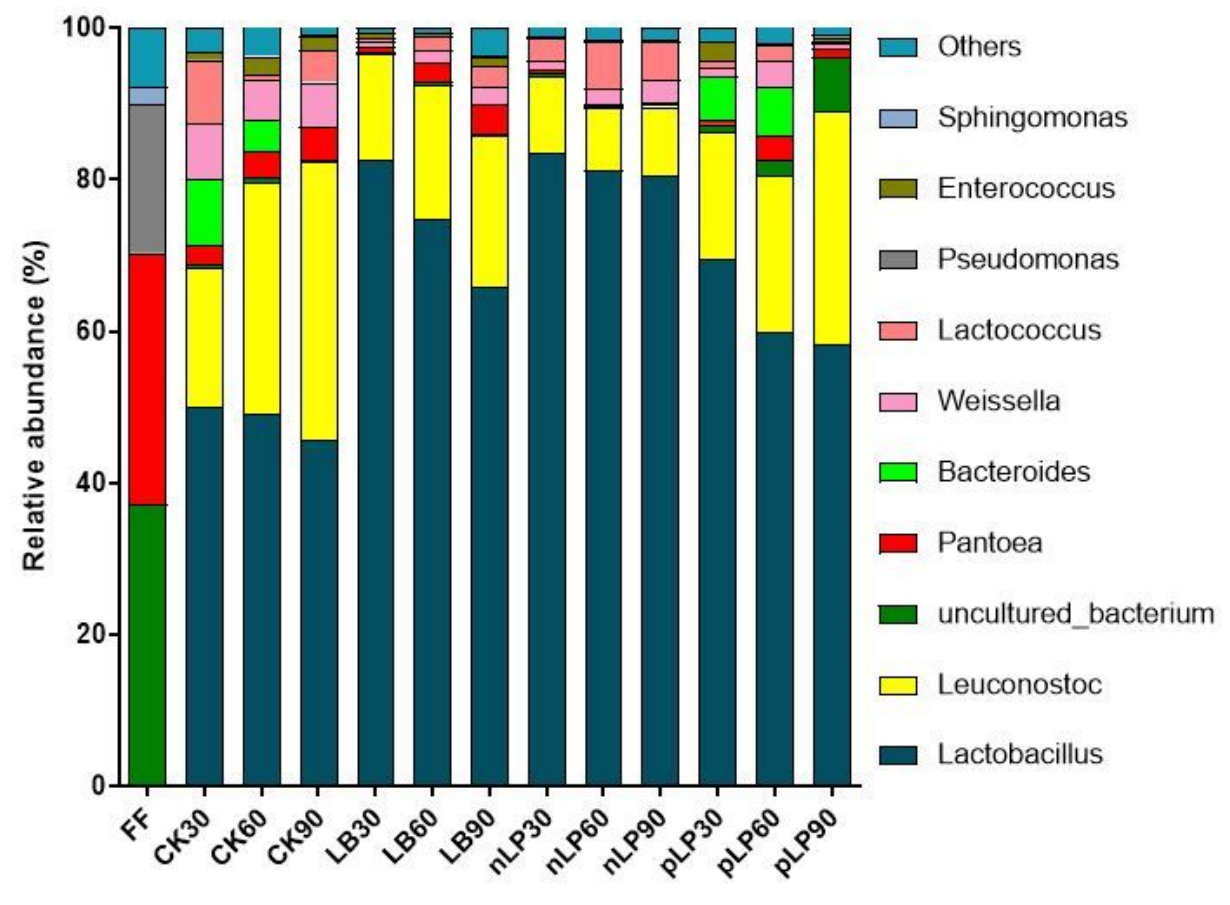

Figure 2

The relative abundance of top 10 bacterial genera of fresh forage (FF) and control without additives (CK) or with functional LAB (LB, L. buchneri; $n L P$, low temperature tolerant L. plantarum; pLP, phenyllactic acid-producing L. plantarum; each application rate of $106 \mathrm{cfu} / \mathrm{g} \mathrm{FM}$ ), and ensiled for $30 \mathrm{~d}, 60 \mathrm{~d}$ and $90 \mathrm{~d}$. 